\title{
La telenovela en mexico: ¿de una expresión cultural a un simple producto para la mercadotecnia?*
}

\author{
GUILLERMO OROZCO GÓMEZ**
}

Se enfatizan en este ensayo algunos de los principales cambios que el formato de la ficción televisiva ha ido sufriendo desde sus orígenes, como relato marcado fuertemente por la cultura y los modelos de comportamiento característicos de su lugar y su época. En este recorrido se hace referencia a la telenovela "Rebelde" producida y transmitida por Televisa en México a partir de 2005. El análisis destaca el tipo de transformaciones formales, estéticas y narrativas que el formato de la telenovela está teniendo y sobre todo su mercadotecnia, argumentos que ayudan a explicar ese fenómeno emergente por el cual la telenovela empieza a "no ser vista" por la audiencia, sino solamente consumida, "comprada".

PALABRAS CLAVE: ficción, televisión, audiencias, telenovela, mercado.
It is argued in this essay that fictional drama in the Tv screen is becoming more and more a simple commodity. If five decades ago, one of the key marks of Mexican Tv drama was its strong cultural identity, and in fact the audience's self recognition in their plots made them so attractive and unique as media products, today telenovelas are central part of mayor merchandizing media campaigns, where ratings-audience's consumption-, not audience's cultural identification, is the most important criterion for its industrial production. By exemplifying with "Rebelde", a successful telenovela produced in Mexico, the discussion in this paper emphasizes the formal, aesthetic, narrative and industrial changes.

KEY WORDS: fiction, television, audience, telenovelas, market society.

* Este texto forma parte de un trabajo mayor de investigación comparada sobre la ficción televisiva realizado en el marco del Observatorio Iberoame- 
La telenovela en México, al igual que en América Latina, ha constituido uno de los espacios de expresión, reconocimiento y recreación cultural por excelencia, a la vez que uno de los productos mediáticos masivos más distintivos y reconocidos de la industria televisiva.

A veces "burlando al género de ficción para acercarse a la vida misma", y a veces burlando a la audiencia para acercarse al negocio puro, la producción, transmisión y recepción de la telenovela ha significado en las culturas latinas un acontecimiento de importancia en la vida cotidiana de sus audiencias, en la construcción de imaginarios individuales y colectivos, en la validación de creencias y expectativas y en la reconfiguración reiterada de esas identidades volátiles, que no obstante dejan sedimentos que perduran por décadas y afloran en los sentires y en los modos de relacionarse unos con otros en los países latinoamericanos.

Con un sello identitario y estilístico propio, la telenovela, como formato del género ficción, también se ha convertido en uno de los productos mediáticos de mayor impacto nacional y de mayor circulación internacional. La telenovela de manufactura nacional llena las pantallas de los principales canales, sobre todo en el prime time, donde se redime la comunicación familiar y se intercambian los afectos y desafectos (ver tabla siguiente).

Al melodrama como género literario y a la telenovela como formato industrial (que lo conlleva) se asocian algunas de las claves más significativas de la identidad de los sujetos sociales-audiencia contemporáneos. A veces re-produciendo y otras des-ordenando los dispositivos de

ricano de la Ficción Televisiva, México (OBITEL). Strictu sensu, este recorrido analítico es un ensayo, no un recuento empírico detallado. Una primera versión de este texto se presentó como ponencia en el seminario "Hacia un estudio de la cultura de masas en la península ibérica: una aproximación comparada", realizado en el Centro de Estudios Avanzados de la Universidad de Santiago de Compostela, Galicia, 21-23 de septiembre de 2005.

** Universidad de Guadalajara.

Correo electrónico: gororozco@udgserv.cencar.udg.mx

1 Frase mencionada por Martín-Barbero, 1992, para referirse a uno de los criterios para la transformación de la telenovela colombiana que adquirió una perspectiva mas costumbrista que la típica telenovela mexicana "a la Televisa". 


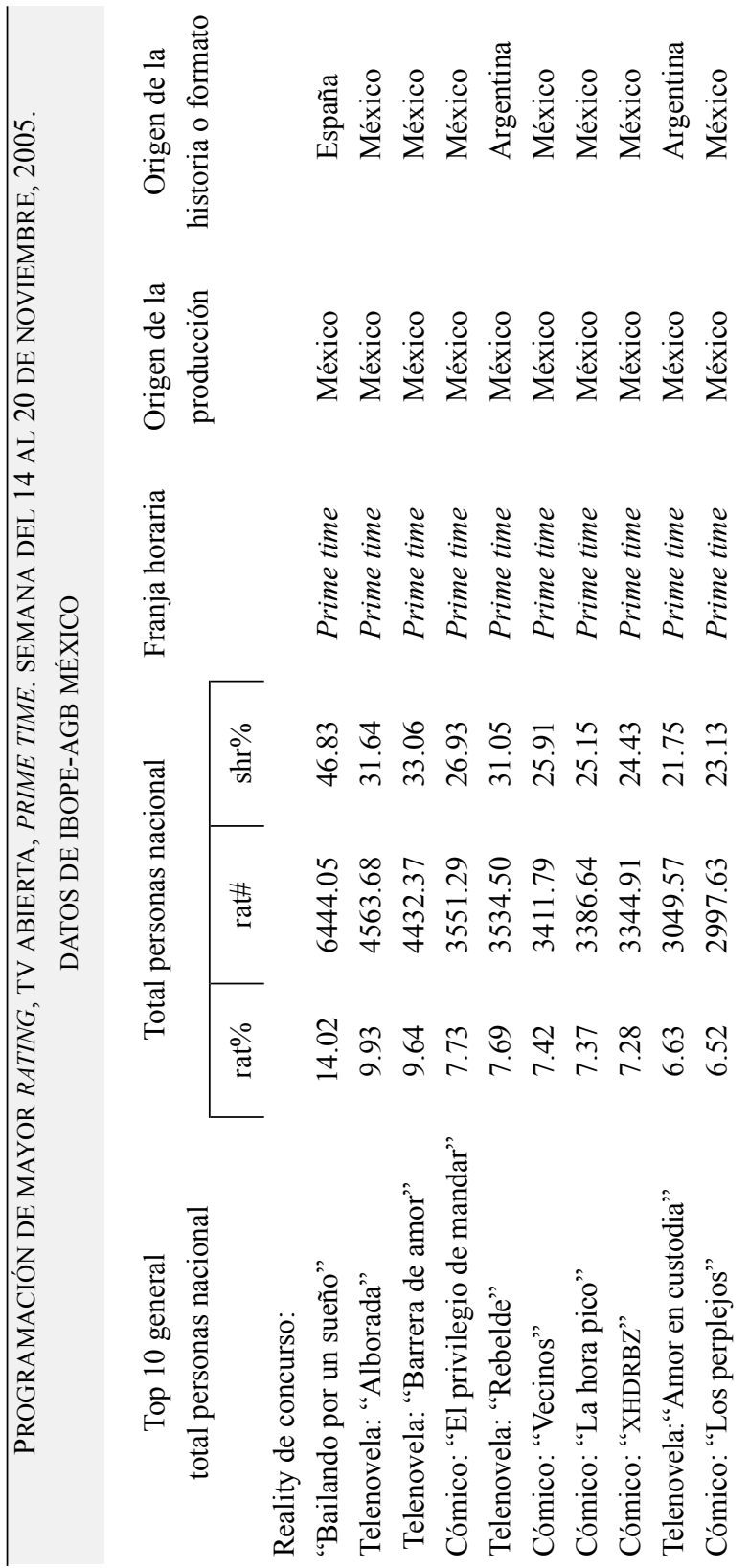


narración y expresión oral y visual vigentes, la telenovela ha inducido reconocimientos identitarios en múltiples segmentos de audiencia, a la vez que ha construido, reproducido y recreado prototipos de clase, de género, de raza y de edad, incluso ancestrales, y petrificado y perpetuado rasgos y características culturales no deseables, como el machismo.

Odiadas y amadas por unos y otros, las telenovelas mexicanas han servido de escenario de integración y síntesis de elementos discursivos, tanto posmodernos como anacrónicos, en una muy peculiar modernidad en la que, por ejemplo, puede darse el caso de que en 2005 una telenovela se llame todavía "La esposa virgen" y la virginidad siga siendo un valor cultural y gancho para el rating $(23 \%)$ a la vez, o que otra telenovela se intitule "La madrastra," y también siga teniendo un rating considerable (21\%), aun cuando el término mismo actualmente se haya desgastado y el tema también haya perdido vigencia y relevancia ante la explosión generalizada del modelo de la familia tradicional y la multiplicidad de opciones familiares y de pareja contemporáneas.

Implosión discursiva o simple reminiscencia terca de un tiempo pasado, en donde las certidumbres dominaban y las identidades se debatían entre el blanco y el negro, entre el ser y el no ser, vírgenes o prostitutas, "madrastras" y/o "amantes", siempre intrusas en las relaciones de otros, "cenicientas" y "simplemente Marías" siguen como arquetipos de ficción en formato de telenovela y prenden fuego entre los televidentes, en quienes seguramente anidan vestigios de tiempos e identidades sólo en apariencia rebasadas, que avivan la flama emocional en sus intercambios con la pantalla televisiva.

Investigadores de la telenovela en América Latina y en México como Martín-Barbero (1992); Mazziotti (1996); González (1998) y Vasallo (2002) coinciden en sostener que en la telenovela reside una matriz cultural de la cual emana su fuerza narrativa y desde donde se hace posible que este género programático interpele emocional y cognitivamente a sus audiencias. Una matriz cultural que a lo largo de cinco décadas había producido a mitad del año 2005 la insólita cantidad de 872 telenovelas (Cueva, 2005a). ${ }^{2}$

2 El periodista Álvaro Cueva ha realizado el seguimiento de todas las telenovelas mexicanas y escrito su ficha técnica, mismas que están publicadas 
La telenovela conjunta, condensa y recrea, quizá como ningún otro género televisivo, lo popular, característico de las grandes mayorías en los países latinoamericanos, con lo melodramático, en tanto emotividad residual en sus intercambios cotidianos, vigente en la mayoría de las interacciones afectivas, interpersonales. Estas matrices culturales, entendidas entonces no sólo como esquemas mentales, sino como "prácticas de conocimiento y comportamiento" -según la propuesta de Martín-Barbero y Muñóz (1992)- permiten comprender la vinculación entre las lógicas comerciales de su producción industrial con las lógicas de su consumo y el ejercicio permanente de las competencias comunicativas de los televidentes.

$\mathrm{Ni}$ todo es nuevo ni tampoco todo es viejo en los melodramas de la televisión mexicana; siempre hay algo que sorprende junto a algo que es completamente esperable y reconocible. Cercanía y novedad, creación y reproducción se conjugan para facilitar un reconocimiento socializable, traducido en narrativas espontáneas entre los que ven la telenovela, y necesario para la revivificación cotidiana del drama, que según el consenso existente entre investigadores de la comunicación y sus medios, es el elemento crucial que le ha dado a la telenovela su mayor distinción frente a otros tipos de dramatizados televisivos y formatos ficcionales, que hace posible diluir las fronteras entre la realidad y la ficción, entre ricos y pobres, entre jóvenes y viejos, o entre nacionales de un país y otro. Como sugiere Vasallo (2004), la telenovela tiene esa gran capacidad de "alimentar un repertorio común" subyacente a lo largo y ancho del continente latinoamericano. Al mismo tiempo, en tanto que recrea el amor y las relaciones afectivas, es un producto "que vende" y que vende en casi cualquier lugar (Carugati y Alvarado, 2005). Como sugiere Mazziotti: "En el contexto de las luchas y los sufrimientos que causan el desempleo, la violencia, la pobreza y la exclusión social [...] la ficción televisiva se convierte en uno de los pocos lugares en donde sueñan, se miran, se refugian, se emocionan y se comparten nuestras precarias y acosadas identidades" (2003:12).

Decidir el dónde y el cuándo empieza, y el dónde y el cuándo termina el capítulo de una telenovela, es a la vez que un desafío, una especie

con fotografías de los protagonistas en un número especial de la nueva revista Alvaro Cueva Presenta, dirigida por Macarena Quiroz, México, septiembre 2005 . 
de acertijo a resolver, que motiva el esfuerzo por entender a este género y sus mediaciones y contextos de recepción dentro de ese otro esfuerzo mayor por entender la cultura, sus transformaciones y los intercambios sociales contemporáneos en tiempo real y en escenarios más allá del salón de ver televisión.

Como narrativa cultural, la telenovela se vuelve punto de convergencia de pasiones y aspiraciones, lágrimas y risas, demandas y gratificaciones, desencantos y alianzas, emociones varias que bordan un espacio imaginario que algunos conceptualizan como "comunidades imaginarias" (Anderson, 1991) en el cual se hace posible una especie de entendimiento mutuo del cual abreva la "mexicanidad", más allá de sus dispositivos nacionalistas. Como sugiere González "la telenovela mexicana es un producto hecho para significar, pero dicha significación anuda y anida en el imaginario con la memoria colectiva" (1998:38).

\section{¿UNA NUEVA ETAPA DE LA TELENOVELA?}

No obstante, en este ensayo sostengo que es en la telenovela, como en ningún otro formato de la ficción contemporánea, donde se lleva a cabo un proceso de transformación, no necesariamente para reforzar la creación cultural y su expresión y reconocimiento, sino para facilitar simplemente su consumo como mercancía de "marca" y exportación, en la medida en que, como señala Maffesoli (1996) "estamos testimoniando la tendencia a reemplazar una realidad 'social' racionalizada por una 'socialidad empática', que es expresada por asociación de ambientes, sentimientos y emociones".

Si desde la primera telenovela latinoamericana ("Senda prohibida", realizada y transmitida en México en 1957) se había venido desarrollando, industrializando y globalizando la producción y circulación de la telenovela, no sólo en México sino en toda América Latina, y se había consolidado una trayectoria particular (Cueva, 2005b), lo que se aprecia hoy en día con las más recientes producciones (como la telenovela "Rebelde" con libreto argentino pero producida y transmitida durante 2005 y 2006 en México por Televisa como remake, o con la telenovela "Amor en custodia", de similares características, pero transmitida por TV Azteca durante 2006), es una explosión narrativa que fragmenta el relato 
melodramático en pequeños spots engarzados bajo criterios variados, a veces formales, otras sensoriales y otras más lingüísticos. Esta explosión cambia el peso y la base de la interpelación del producto de ficción; la "nueva" telenovela ya no parece estar tan preocupada por reflejar una interpretación y recreación adecuada de la cultura, y por tanto tampoco en posibilitar ese reconocimiento identitario por parte de los televidentes. ¡La telenovela y quienes la realizan hoy en día parecen estar simplemente preocupados por venderla! Para ello junto con la telenovela se despliega toda una "estrategia de marketing". Y esta estrategia, independientemente del reconocimiento por parte de la audiencia, busca solamente su aceptación. La telenovela, entonces, muestra imágenes atractivas, como las de sus actores, semidesnudos masculinos y femeninos, y muestra rasgos de moda, tanto en el vestido como en el lenguaje y los gestos, que al presentarse con caras y cuerpos atractivos se hacen apetecibles a los ojos de los televidentes, y por tanto consumibles.

Este fenómeno de mercantilización, donde el éxito de la compraventa del producto es lo que le da cierta naturalización y se antepone a otros criterios de estética, calidad técnica y dramática o de innovación, había sido anticipado y advertido hace más de una década por MartínBarbero, cuando escribía que una de las preocupaciones de fondo con la telenovela es ese fuerte

...enlace entre cultura y negocio, no ya en aquel sentido apocalíptico y fatal que de manera abstracta confunde lógica mercantil y formato industrial, negándole cualquier valor cultural a los productos de la industria televisiva, sino tratando de entender lo que el negocio de la cultura tiene de negociación, esto es de mediación específica entre las lógicas del sistema productivo - estandarización y rentabilidad-y las dinámicas de la heterogeneidad cultural (1992:12).

La exacerbación de lo mercantil, en los últimos años, como motor de la producción de telenovelas, y en general de toda la producción mediática, hace que la telenovela empiece a "no ser vista", sino simplemente consumida. Hay indicios para sospechar que su aceptación y popularidad no dependen ya tanto de elementos como la calidad de la actuación de sus protagonistas, ya que estos son cada vez más improvisados, independientemente de que puedan tener otros talentos musica- 
les o dancísticos, o haber salido de la "constelación" de estrellas de las empresas televisivas, como es el caso de varios de los protagonistas de "Rebelde" y de "Amor en custodia". ${ }^{3}$

No obstante que la calidad de la producción sea importante para tener una mercancía competitiva, un capítulo de telenovela de una hora de duración, producida por Televisa, asciende a 70000 dólares; por TV Azteca alcanza un tope superior hasta de 50000 dólares, aunque el promedio anda en 40000 dólares, lo cual es mucho menor a lo que invierte Rede Globo de Brasil, cuyos costos de producción por capítulo oscilan entre 70 000 y 100000 dólares. ${ }^{4}$ De manera contrastante al costo en la producción, Televisa ha aumentado sus ganancias en el cuarto trimestre de 2005 en $7.1 \%$, a partir de programas de ficción y "reality", y el aumento anual durante 2005 alcanzó 5.1\%, que equivale a 18 mil millones 570.6 pesos; cifra que es superior al aumento del año 2004, que se ubicó en 17 mil millones 671.9 (Grupo Televisa, 2006). 5

Existe otro dato que nos podría ayudar a ilustrar hasta qué punto las compañías televisoras buscan obtener una ganancia monetaria con la transmisión de ciertos programas (fundamentalmente ficción) en franjas horarias específicas como la llamada prime time que corre desde las 7 de la tarde hasta las 10 de la noche, un horario en el que se difunden telenovelas en las dos cadenas (canal 2 de Televisa y el Canal 13 de TV Azteca). Un ejemplo: de las 9 a las 10 de la noche Televisa, en su Canal 2, vende su espacio publicitario a razón de 348700 pesos por spot publicitario de 20 segundos. Si tomamos en cuenta que en promedio, durante la transmisión de un programa de una hora de duración, hay tres cortes publicitarios con 20 spots cada uno, hablaríamos de que Televisa obtiene alrededor de 20 millones de pesos (casi 2 millones de dólares estadounidenses) como resultado de la venta de su espacio de publicidad en prime time (IBOPE-AGB, 2006). ${ }^{6}$

3 Vertele.com “La guerra de los culebrones", Enero 2006, Consulta en línea: (www.vertele.com/noticia_01.phtml?id=11718)

4 Video Age, "Producción de telenovelas: es cuestión de dónde son filmadas", enwww.videoagelatin.com/articulos/Oct01/novelas.htm.

5 Compartimos con Daniel Mato, la importancia de analizar datos económicos en el estudio de la ficción. (Ver Mato, 1999).

6 Tarifas correspondientes al segundo trimestre de 2006. 
Ahorrando en ensayos y tiempos de producción, la propaganda y la promoción se despliegan en productos, tanto de los que llevan el nombre de la telenovela, desde camisetas, hasta artículos de tocador, muñecos de peluche, fotografías, goma de mascar, etcétera, como a través del anuncio cada vez más explícito de las marcas de los productos que usan e intercambian "naturalmente" los protagonistas en cada capítulo de la telenovela.

La telenovela, en la actualidad, parece "salirse de la pantalla", pero brincando ese espacio inmediato del "reconocimiento socializable" de sus televidentes, para estar en todas partes; sus imágenes acechan en las vitrinas y lugares públicos y esa cuasiomnipresencia al parecer la hace irresistible, pero de manera distinta a aquella otra telenovela menos reciente, que también llegó a ser amada, e incluso, convocó a más televidentes que ahora. Por ejemplo, mientras que la telenovela "María Isabel" en 1966 alcanzó un rating nacional en México de 53.6 (Torres, 1991) en los últimos 5 años ninguna de las telenovelas "nuevas", ni siquiera "La madrastra", ha alcanzado más de 25 puntos (IBOPE-AGB, 2006). Cabe preguntarse: ¿será que sí importa lo que exprese una telenovela, y no sólo lo que incite a comprar? ¿Cuál es ahora la experiencia inmediata gratificante que brinda a sus televidentes? ¿Cualés son los (nuevos) motivos para su compra o a qué motivos apela la nueva telenovela? Por otra parte, motivos que no todos comparten, y que hacen que en algunos países hispanoparlantes se hable de un decrecimiento en la popularidad del melodrama, por lo menos del melodrama tradicional (Cueva, 2005b). Al mismo tiempo, crece la globalización de la telenovela y empieza su producción en serio en los Estados Unidos (Bruno, 2005). ¿Estamos ante la inauguración de un nuevo contrato social, fuertemente mercantil, entre el melodrama televisivo y sus audiencias?

\section{ORÍGENES Y CONTEXTO}

DE LA TELENOVELA EN MÉXICO

Entender el surgimiento y desarrollo de la telenovela supone hacer explícitos algunos reconocimientos como punto de partida. Primero, que el género de telenovela como formato audiovisual en serie se origina en los Estados Unidos, en donde se convierte en soap opera, ya que las 
producciones bajo este formato en sus primeras décadas (de 1950 y 1960) fueron casi siempre patrocinadas por compañías de jabones y artículos de limpieza, tales como Palmolive o Colgate (Torres, 1991). La diferencia central entre una soap opera y una telenovela mexicana estriba tanto en su "estructura narrativa" como en su "duración" (Frey-Vor, 1993). Mientras que la soap opera es mucho más larga, puede durar años incluso, como "Dallas" en los años 70, o "La caldera del Diablo", importada y transmitida en varios países de Iberoamérica también en esos años, la telenovela mexicana oscila entre 90 y 120 capítulos a lo sumo, y tiene una narrativa y final menos abiertos. Se trata de narrativas más melodramáticas, y finales casi siempre reivindicativos del sufrimiento de los protagonistas a lo largo de los capítulos, que permiten afirmar que en la producción televisiva hispanoamericana, si no se puede anticipar exactamente cómo terminará una telenovela, ipor lo menos se puede saber de antemano cómo no podría terminar! Y la ruptura de esta tradición o pacto entre ficción televisiva y audiencias hace que los televidentes se sientan traicionados por el género televisivo, que justamente conlleva arreglos y acuerdos que no pueden violarse (Padilla, 2004).

Un segundo reconocimiento tiene que ver con el origen más remoto de la telenovela, que es el de su secuenciación, en la que formalmente se estructura una trama en episodios cortados por efectos de suspenso, y continúan al día siguiente resolviendo la expectación de los televidentes que quedaron "suspendidos" emocional y cognoscitivamente. Esta secuenciación se origina en el folletín europeo del siglo XIX, que en diferentes "entregas" completaba una narración a sus ávidos lectores. La seriación del relato, entonces, aunada al desarrollo enfático en lo melodramático, por el cual el drama es definido en sus aspectos más afectivos, más de "sentires" que de acción, son quizá los dos elementos claves que conforman esa "magia" de la telenovela, que atrapa y hace soñar a sus televidentes, pero también sufrir y conmoverse hasta las lágrimas, que a fin de cuentas es en y con la ficción, no en y con las noticias, donde sí se puede "llorar a gusto" (Orozco, 2002a).

Un último reconocimiento tiene que ver con que la telenovela en México y en América Latina, a diferencia de lo que ha sucedido en países de habla inglesa con las soap operas e inclusive en Brasil con sus propias telenovelas, prosigue de una beta de narrativa dramática propia de la 
radionovela (Monsiváis, 2000). Radionovela que tuvo su esplendor en la primera mitad del siglo, primero en Cuba y luego en el resto del continente. La actuación remarcada de los personajes junto a un mayor protagonismo de la palabra hablada, no de los gestos o de lo visual, ha permitido calificar a muchas telenovelas, sobre todo de las primeras décadas, como "radionovelas escuchadas en pantalla". Esto también se explica porque tanto en México como en Colombia o Venezuela, por citar sólo tres de los países latinoamericanos productores de este género televisivo, su producción arranca con empresarios de la radio, como Emilio Azcárraga Vidaurreta, abuelo del actual presidente de Televisa en México, que extienden su dominio mediático de la radio a la televisión, para lo cual trasladan técnicas, lógicas de producción, géneros y estrategias propias de esa industria. Por supuesto que también emigran de un medio a otro la mayoría de los actores (Orozco, 2002b). Esto significa que tanto en términos de estilo de actuación como de producción industrial, la telenovela mexicana proviene de una tradición oral, más que visual o de otras fuentes, y como en la radio, buena parte de lo que acontece siempre es bajo techo, casi siempre ¡en el mismo lugar del escenario!

Diferenciada de la soap opera, así como de esa otra telenovela brasileña que pone más énfasis en reflejar cotidianeidad y en abordar problemáticas de fondo, no sólo relaciones amorosas, la telenovela mexicana se ha ido consolidando, primero como un género para la mujer: "El amor tiene cara de mujer" (1971), "Simplemente María” (1970) o "Corazón salvaje, 2" (1977), que siempre se transmitieron en horario vespertino. Luego se instala como una programación para la audiencia adulta masculina y femenina: "Cuna de lobos" (1986), que inaugura su transmisión en horario nocturno en México, o "Yesenia" (1970), que es a su vez la primera telenovela transmitida en domingo en prime time.

Posteriormente, la telenovela se dirige también a las audiencias jóvenes, que es el caso de telenovelas como la mexicana "Acompáñame" (1977) o la reciente de libreto argentino "Rebelde" (2005). Para las audiencias infantiles la oferta ha incluido títulos tan exitosos como la argentina "Chiquititas" (2000), que se rehizo en varios países con sus latinidades particulares.

Sin perder su carácter melodramático ni menos aún el rango de rating conseguido por las clásicas telenovelas de amor, en México se experimen- 
tó durante la década de 1970 y principios de los años 80 la producción de telenovelas de contenido social. Miguel Sabido fue su promotor desde Televisa misma, y las producciones que realizó tuvieron mucho éxito; se enfocaron en temas como la planificación familiar, la alfabetización de los adultos, el valor de la familia o la paternidad responsable. Algunas de ellas se hicieron en coproducción con la Secretaría (Ministerio) de Educación Pública y otras con el Ministerio de Salud. Los títulos de estas telenovelas reflejan la intención pro social: "Ven conmigo" (1976), “Acompáñame" (1977), "Vamos Juntos" (1979), "Caminemos" (1980). Es importante destacar que una de las últimas telenovelas de este corte constituyó una innovación temática, a la vez que una decisión arriesgada, ya que tocó un tema importante, pero muy difícil en un contexto subcultural machista. "Nosotras las mujeres" (1981) fue la producción que, junto con las anteriores, también se exportó y, como afirma Torres (1991), Televisa asesoró la producción de programas similares en otros países, como India y Kenya.

Por otra parte, a lo largo de sus cinco décadas, según Mazziotti (2005) se han ido distinguiendo por lo menos cuatro tipos de telenovela hispanoamericana: el modelo Televisa, el modelo costumbrista (colombiano), que tiene sus variables según una telenovela se produzca ahí o en Argentina o Chile, y el más reciente, el modelo Miami, además del modelo brasileño (reconocido por esta autora como el modelo Rede Globo.).

\section{EL MODELO TELEVISA ${ }^{7}$}

La telenovela mexicana, engendrada y "llevada a la gloria" por el consorcio Televisa, es -según Mazziotti-, el modelo "tradicional"; conlle-

7 Mazziotti (2005) sugiere que en la región latinoamericana hay, además del modelo Televisa, otros tres más: el colombiano, que yo identifico como un modelo "costumbrista", el brasileño, por supuesto, que es el modelo que incorpora los temas de la vida contemporánea según la perspectiva social vigente, y el modelo Miami, que reconozco como un modelo "panamericano", que involucra diversas latinidades, como esa telenovela que está teniendo tanto éxito no sólo entre comunidades hispanas de los Estados Unidos, sino también en España: "Pasión de gavilanes". 
va temas y narrativas fuertemente sustentadas en el teatro y en la radio de la década de 1940. Una especie de "moral cristiana" permea la perspectiva humana desde donde se vive el drama y el conflicto, ya que

No se cuenta sólo una historia de amor, sino de un absoluto, de la justicia esencial, de una reparación moral y hay una enorme gravitación de la culpa (2005:1).

Pero sobre todo, "la redención" del o los personajes se hace posible por el sufrimiento, clásico tema ejemplificado magistralmente en esa famosa telenovela "Los ricos también lloran" que dio vuelta al mundo y cosechó audiencias tanto en Europa como en Rusia, China y Medio Oriente.

Con libreto escrito por Inés Rodena y transmitida en 1980, esta telenovela, además, es un caso prototipo de exportación de un producto cultural que tiene un elevado éxito en otras culturas, muy diferentes entre sí. Quizá porque se toca lo "elementalmente humano".

Con este esencialismo, que deviene luego en un marcado maniqueísmo entre los personajes, la telenovela mexicana más que recrear a una mujer buena o mala, recrea la bondad o la maldad en la mujer. Esto se consigue gracias a que

el relato se construye con personajes arquetípicos, caracterizados por un único rasgo, que está marcado no sólo por su discurso sino también por el maquillaje y el vestuario. (ibid.:2).

Asimismo, si bien el epicentro de la trama es una relación afectiva que deriva en otras, en ella no hay sensualidad o erotismo; quedan reprimidos, pero salen en momentos a borbotones, por lo que siempre son burdos, dignos solamente de la maldad y de aquellas o aquellos que la encarnan, como esas relaciones violentadas en la telenovela "Contra viento y marea" (México, 2005), por cierto de libreto escrito por un autor venezolano.

La telenovela "a la Televisa", cuando cuenta una historia, remite a pasados conformados con esencias de clase, de género, de valores universales que se hacen perdurar aun en el presente, como la virginidad, el esfuerzo como estrategia del pobre para progresar legítimamente en la vida y la astucia como estrategia del rico para sobrevivir a la desgracia 
y reencontrar su destino, etcétera. El color de la piel y los rasgos de raza son ocasión para el "amor imposible" entre la mujer blanca y el hombre rudo, como en "Corazón salvaje", donde el personaje Juan del Diablo tiene que realizar su amor con la esposa del patrón a escondidas por los rincones de la hacienda, lo que, sin embargo, le dio tanto atractivo (¿morbo?) a la telenovela; fue tan exitosa que se rehizo en cada década a partir de su primera producción, la de los años 70 .

No obstante la permanencia de los principales hilos que tejen la madeja melodramática de este modelo "tradicional" de telenovela, lo que sí se renueva son los actores y actrices; ¡siempre hay caras nuevas! El star system de Televisa es una fuerte maquinaria mercantil que engendra y hace obsoletas, a la vez, a todas las figuras que transitan por su pantalla, desde las históricas "lloronas" Amparo Ribelles o Silvia Derbez, -famosas por sus conmovedoras interpretaciones en la telenovela "Lágrimas amargas" de Yolanda Vargas Dulché- hasta Angélica María, Lucía Méndez, Verónica Castro o Thalía.

La renovación existente en este modelo, entonces, está en sus estrellas y al parecer se mantiene, exacerbándose en las más recientes producciones, como "Rebelde" o "La esposa virgen". No por nada el Canal 2 de Televisa, donde se transmiten la mayor parte de las telenovelas en México, lleva por nombre "El Canal de las Estrellas".

\section{LA TELENOVELA QUE REGRESA}

\section{A LO LOCAL A TRAVÉS DE LO GLOBAL}

Con este título, el investigador estadounidense Lull (1998) explica el fenómeno de la globalización de la telenovela mexicana. Según este investigador, a diferencia de otros productos mediáticos como las noticias, la ficción -sostiene- no es una instancia de lo global en lo local, como algunos pretenden verla, sino algo muy local que se dispara en múltiples direcciones y cruza fronteras.

Alcanzar este estado ha significado para la telenovela en México un desarrollo industrial sostenido tras pasar por varias etapas. Mazziotti (1996) sugiere cuatro, a las que aquí agrego una quinta.

La primera etapa, la inicial, arranca en 1951 con telenovelas que se transmitían en vivo y que eran fieles seguidoras de las radionovelas. 
Si notamos que la televisón comercial en México se inaugura en 1950, vemos que el formato telenovela arranca desde sus orígenes. Se le denomina a esta etapa la "prehistoria", ya que sólo hay testimonios escritos acerca de las telenovelas y algunas fotografías. No obstante, hay un cierto debate sobre si la telenovela de esta etapa fue tal o más bien una serie con capítulos, que a su vez concluían.

La siguiente etapa, la artesanal, se inaugura en 1957 con la grabación en videotape de las primeras telenovelas. Al decir de Mazziotti:

... el videotape permitió dos cosas, por una parte su circulación y venta como enlatado y por otra, otorgó a la producción un mayor grado de verosimilitud escénica, ya que los errores podían ser subsanados a través de un posterior montaje. (1996:29)

El cambio tecnológico que se produjo con la posibilidad de grabar la producción y editarla posteriormente fue clave para el desarrollo de la industria de la ficción televisiva. Y son quizá los desarrollos de este tipo, como el "apuntador electrónico" lanzado al mercado en los años 70 -indispensable en la telenovela mexicana-, los que han permitido su enorme industrialización. En esta etapa comienza el auge de los buenos libretos de autores de diferentes países, que se venden a otros países para su producción doméstica. Las telenovelas comparten mucho entre sí, tanto del eje central melodramático, como de las innovaciones que acaban siendo "variaciones sobre un mismo tema". El tema predominante es la necesidad de reconocimiento por el otro, lo que significa el reconocimiento del hijo por su madre o su padre desconocidos, reconocimiento de la madre por su hijo, del abuelo rico por el nieto desaparecido, del hermano por el hermano, en fin, reconocimiento de la que sufrió tanto por los que la rodean, y reconocimiento del que ama en secreto sin poder confesar su amor por la persona amada, etcétera.

Los títulos de las telenovelas, ya desde esta etapa, expresan mucho de los énfasis temáticos y permiten ver esas variaciones al "amor telenovelesco" entre países. Mientras que en las telenovelas mexicanas predominan títulos que enfatizan amores pecaminosos e imposibles como: "Cadenas de amor" (1959), "Amar fue su pecado" (1960), "Estafa de 
amor" (1961), "Agonía de amor (1963), "Siempre tuya" (1964), "Secreto de confesión" (1965), "Amor y orgullo" (1966), "Amor sublime" (1967), "Cruz de amor" (1968), "Puente de amor (1969), "El precio de un hombre" (1970), "La Hiena" (1973), "Pacto de amor" (1977); los títulos de telenovelas argentinas de la época enfatizan amores menos atados y hasta imaginados, como serían: "Amor en Si bemol" (1959), "Adorable juventud" (1963), "Amor a toda hora" (1961), "El amor tiene razón" (1965), "Cada uno por su lado" (1966), "Estación Retiro" (1971), "El hombre que yo inventé" (1977).

En la etapa siguiente, de industrialización, una característica sobresaliente fue la diferenciación de las temáticas y los tratamientos. Esta etapa va de mediados de los años 70 hasta finales de los 80 . En estos años se consolida la producción industrial, sobre todo en tres países: México, Brasil y Venezuela, de donde se exportan telenovelas al resto de los países de habla hispana. Es en esta etapa donde también se consolidan las empresas de televisión en varios países. Televisa en México, Rede Globo en Brasil, Venevisión en Venezuela. Estos consorcios crecen con el apoyo de sus respectivos gobiernos, en alianza con los políticos en turno y logran, de esa manera, pero a costa de los televidentes, consolidar "imperios mediáticos en el Sur".

Es quizá debido a estas alianzas con los poderes establecidos que la ficción en México no toca temas políticos, salvo en excepciones, como la telenovela mexicana "Nada personal" realizada por una productora independiente, Argos, en medio de la "Guerra de las televisoras" mexicanas entre 1997 y 1999.

La "imagen de país" que transmiten las telenovelas mexicanas es una imagen casi siempre idílica, velada, intuida por algunos diálogos de los personajes, nunca explícita. La problemática nacional pareciera no existir o quedar "eclipsada" ante la sentimental. En parte debido a que ha estado prohibido romper las alianzas entre poder mediático y poder político, las empresas televisivas no han intentado abordar otros problemas que no sean los interpersonales, de pareja o familiares.

¡La política parece no caber en el melodrama tradicional! Este se vive siempre en persona o en familia, en la intimidad, no en el espacio público. En la telenovela mexicana, cuando se toca un tema político, como una guerra, lo que sobrevive en la memoria colectiva de los per- 
sonajes no es la guerra como tal, sino el recuerdo de una persona ausente, y se expresa como: "aquel tiempo cuando murió mi madre".

Independientemente de que se pueda o no achacar al melodrama televisivo el diluir conscientemente la política por razones de su formato, es muy claro que en el caso mexicano, por lo menos, ha habido una voluntad por quitar lo político de la pantalla, para no enojar a los políticos en turno (Orozco, 2004).

En la cuarta etapa, la de transnacionalización, que corre en los años 90, las telenovelas mexicanas no sólo transitan por los países de la región de múltiples maneras, a través de sus libretos, de sus actores, o como productos terminados, sino que viajan por el mundo. Se convierten en un fenómeno de audiencia. Son capaces de movilizar a poblaciones enteras que, a la hora de su transmisión, suspenden otras actividades. En esta etapa la producción sistemática de telenovelas se consolida en varios países latinoamericanos, y sus telenovelas se exportan con mucho éxito. La mexicana "Yesenia 2", por ejemplo, llega a China y es vista por millones, "Los ricos también lloran” es vista por ¡70\% de la población rusa! (Mazziotti, 1996).

Es justamente con la comercialización transnacional de la telenovela que se consolida su compraventa como producto cultural, que no obstante su éxito comercial sigue manteniendo hasta finales del siglo pasado fundamentalmente el mismo tipo de narrativa, con los matices propios del modelo al que pertenezca. Asimismo, es con la telenovela que los países de América Latina entran a competir con Europa y los Estados Unidos en la producción e internacionalización de ficción televisiva. Independientemente de que el intercambio comercial en este rubro siempre haya tenido un cierto desequilibrio en contra de los latinoamericanos, es indudable que en ese mercado mundial la telenovela se posicionó contundentemente como un producto con denominación de origen.

Este reconocimiento de marca está revolucionando la producción de telenovelas tanto en México como en los países de América Latina, y aun en Estados Unidos. Como se aprecia en el cuadro siguiente, va aumentando el número de telenovelas cuya idea original o guión es hecho por autores de nacionalidad distinta a la de la producción final de la telenovela. 


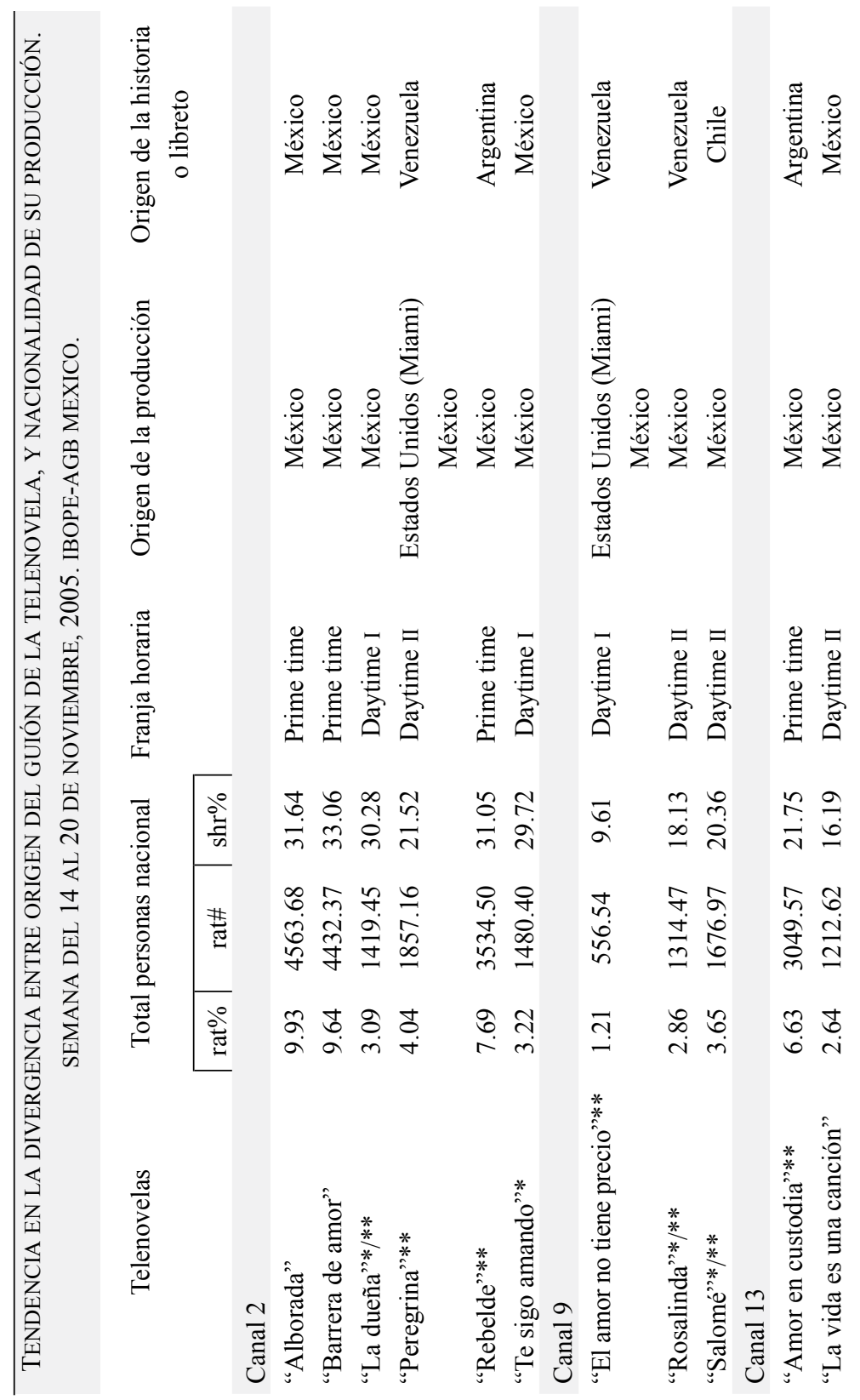




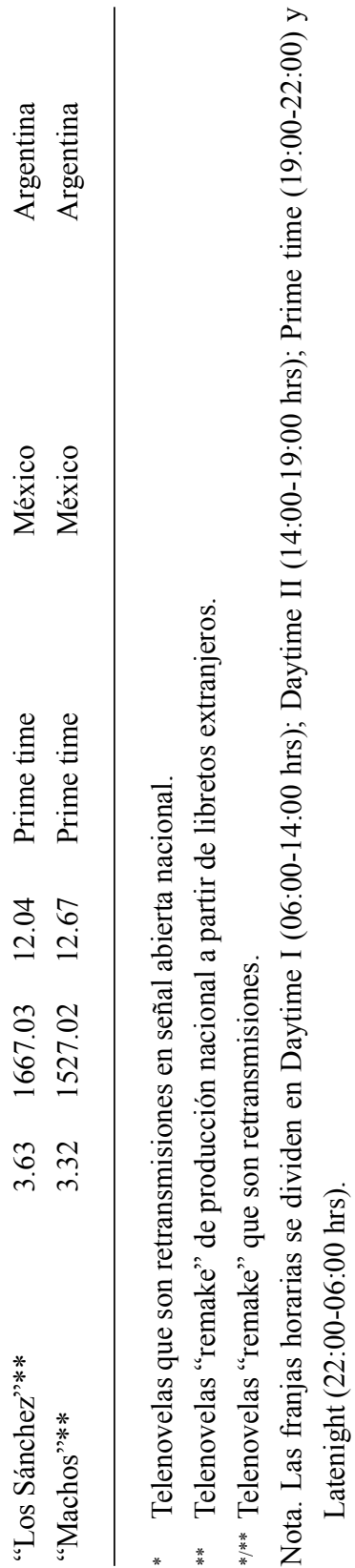


Es interesante resaltar el caso de la telenovela "Mirada de mujer", 1997, remake producida en México, pero por primera vez no por Televisa sino por Productora Argos, transmitida por TV Azteca, que llegó a ser promovida en esta como "la nueva telenovela mexicana". Es en esta etapa donde se hacen algunas experimentaciones con cambios, tanto en las temáticas como en sus tratamientos, por lo menos en el modelo tradicional melodramático.

En la etapa actual (año 2000 en delante), que aquí denomino de mercantilización, la telenovela en México empieza a ser hecha ante todo para venderse -como indiqué al inicio de este ensayo-. Para ello, no sólo se hace explotar su narrativa tradicional en el intento por provocar expectación en los televidentes, sino que también se introducen múltiples relatos simultáneos hilvanados "caprichosamente", casi al estilo "videoclip".

La introducción de múltiples historias, como en los casos de las telenovelas "Rebelde" y "Amor en custodia", redunda en una variedad de melodramas dentro de uno mayor, en cuanto a contenido se refiere. No es casual que se introduzcan varias historias, lo cual ya solía ser costumbre en otros formatos de esta ficción, como las series norteamericanas. Con este recurso se logra diversificar a los protagonistas y se aumenta relativamente la expectación de los televidentes, a la vez que afecta en aspectos formales de producción, ya que aumenta la acción y la agiliza. Otro de los cambios mayores en la nueva telenovela es el número de escenas que se incluyen por capítulo. Usualmente su número fluctuaba entre 12 ó 14, mientras que en las más recientes los capítulos están compuestos, en promedio, por 50 escenas. Aunado a lo anterior, aumentan también las escenas en exteriores (Carugati y Alvarado, 2006).

Estos cambios son importantes porque rompen con una tradición larga de la telenovela en donde casi no pasaba nada, excepto que los varios personajes se regodeaban en contarse unos a otros lo poco que ocurría y de esa manera lograban el beneplácito de las audiencias, y donde lo poco que pasaba siempre se desarrollaba en interiores.

Por otra parte, al fragmentar la narrativa central también se da cabida a lo insólito, que puede ser la presencia de un personaje que emula a un fantasma, como el de la maestra vestida de negro y cubierta completamente hasta la cabeza, que deambula sin identificarse como sombra 
por los pasillos de la escuela "Elite way" en la telenovela "Rebelde", o la madre de una de las estudiantes que, en la misma telenovela, se presenta en la escuela siempre "des-vestida", como para una pasarela de modas, dejando ver tanto de sus exuberantes carnes que "necesariamente" produce un impacto en los televidentes. Así, a través de efectos narrativos añadidos, como el de suscitar la confusión, desviar la atención del televidente de la escena, exagerar intercambios hasta el nivel de la espectacularización, ridiculizar a algún personaje, e incluso desenfatizar la buena actuación, el relato se interrumpe quedándose como pretexto de fragmentos narrativos desconectados entre sí y sólo verosímiles por su remoto anclaje con un supuesto tema central, no narrativo, que en el caso de "Rebelde" podría ser el "tratar de ser joven a pesar de todo".

En este tipo de relato lo melodramático se reduce, a la vez que aumentan los efectos espectaculares con los cuales se busca atrapar la atención del televidente. Se elimina el esfuerzo de seducción, históricamente característico de la telenovela en América Latina, por el cual se ponen en juego diferentes elementos y artificios de manera más bien cadenciosa (Ferrés, 1998) para dar cabida a la mera excitación al consumo. Por eso el formato de spot, propio de la publicidad comercial y la propaganda política, también se introduce para encuadrar ahí diferentes intercambios.

Pareciera que más que lograr un reconocimiento socializable entre la audiencia, la nueva telenovela buscara producir su consumo sensorial. Reforzando la tendencia creciente sugerida por Gittlin (2002), de que lo que importa realmente es el conjunto de sensaciones condensadas en la experiencia que se produce frente al televisor. En la medida en que esta se logre, la nueva telenovela se siente y se vive.

En la actual etapa mercantil se le da un leitmotiv a la telenovela, con el cual, como en la publicidad comercial, el televidente logre identificarse y así se facilite la compra de lo publicitado. En la telenovela que uso de ejemplo, "Rebelde" ese leitmotiv es justamente la rebeldía. No importa si es una auténtica rebeldía o los personajes se rebelan contra lo que vale la pena rebelarse; flota en las interacciones de todos los personajes, sobre todo entre los jóvenes y los adultos, o los que representan alguna autoridad; es reaccionar y confrontar al 
otro; ese no obedecer, ese no ajustarse a ciertas mínimas reglas sociales de la convivencia.

Si a mediados de 2006 se pueden contabilizar 885 telenovelas -siguiendo la cifra de base que aporta Cueva en el 2005-, hacia final del año serán casi 900 títulos los que llegarán a transmitirse en la pantalla mexicana. De esta vasta producción se destacan novelas en las que se realizan cambios, por ejemplo, entre géneros televisivos, cuando se incorpora una dimensión de realidad, esto es, de género "reality" en la trama de la ficción, o cuando se incorporan al melodrama, siempre serio, escenas cómicas o ridículas y aun satíricas propias del género de comedia, como en "Amor en custodia", que transmite en 2006 Canal 13 de TV Azteca en su horario estelar (Martín Etcharen, 2006). Esta hibridación de géneros es actualmente una tendencia creciente en la producción de ficción en México y en América Latina. Asimismo, la introducción de temáticas cotidianas, efervescentes cultural o socialmente, cada vez tienden a ser incorporadas de alguna manera en las telenovelas recientes, aunque no siempre de manera explícita en la producción mexicana, contrastando con la producción de telenovelas históricas o de época, como "Alborada", transmitida por Televisa durante los primeros 3 meses de 2006, en donde lo distintivo fue la construcción del escenario y del vestuario, que con detalle buscaron reproducir la época.

Para cerrar este ensayo me parece relevante mencionar el "gran cambio" que se está realizando hoy en día con respecto a la producción de telenovelas en el escenario internacional. Este cambio es severamente mercantil y consiste en que aceptando que la telenovela ha probado ser el "gran negocio del amor" (Carugati y Alvarado, 2005) y su popularidad se ha incrementado en muchos países, se inaugura la fórmula de "franquicia" en su producción (Morales y Zarur, 2006). Así, la famosa telenovela colombiana de autor colombiano "Yo soy Betty, la fea", cuya versión mexicana, "La fea más bella", que produce Televisa con la polifacética actriz Angélica Vale en el rol estelar, está siendo producida por Salma Hayek en Estados Unidos, y podrá ser reproducida en otras latitudes de acuerdo al esquema mercantil de franquicia por el cual no sólo se compra el libreto, sino también una serie de indicaciones y elementos que no pueden modificarse para garantizar el producto de origen. 
El clamor general entre los productores de telenovelas y las empresas televisivas parece coincidir en considerar a la telenovela ya no sólo como un simple producto de ficción televisiva, sino como todo un modelo de negocios en sí misma.

\section{Bibliografía}

ANDERSON, Benedict (1991) Imagined communities. Londres: Verso. BRUNO, Adriana (2005) "La telenovela vuelve a romper corazones". En Clarín, 28 de junio. Buenos Aires.

CARUgATI, Anna y María Teresa Alvarado (2005) "The business of love" en World Screen, junio. Miami. Consulta en línea: (www. worldscreen.com/print.php?filename $=0605$ novelas.htm).

Cueva, Álvaro (2005a) Qué flojera me dan los refritos. En PúblicoMilenio, 7 de mayo. Guadalajara, México.

-(2005b) Revista Álvaro Cueva Presenta. Edición especial, núm. 1, septiembre. México: Ediciones Álvaro Cueva.

FREY-VOR, Berlinde (1993) "Evolución reciente de la soap opera y su estudio". En Revista de Ciencias de la Información, núm. 8 extraordinario.

FERRÉS, Joan (1998) La televisión subliminal. Barcelona: Paidós.

GiTTLIN, Tod (2003) Media unlimited how the torrent of images and sounds overwhelms our lives. New York: Owl Books.

GONZÁLEZ, Jorge (1998) La cofradía delas emociones (in)terminables. En Jorge González (1998) (comp.) La cofradía de las emociones (in)terminables. Guadalajara: Universidad de Guadalajara.

GRUPO TELEVISA, S.A. (2006) Resultados financieros del cuarto trimestre y año completo 2005, consulta en línea: (www.esmas. com/televisahome/inversionsistas/trimestral72005/514860.htm).

IBOPE-AGB México (2006) "Reporte de la semana 14 al 20 de noviembre, 2005", Información solicitada por OBITEL México.

LULL, James (1998) “Telenovela: la seguimos amando". En Jorge González (comp.) La cofradía de las emociones (in)terminables. Guadalajara: Universidad de Guadalajara.

MAFFESOLI, Michel (1996) The time of the tribes. Londres: Sage. MARTÍN-BARBERO, Jesús (1992) "El proyecto: producción, composición y usos del melodrama televisivo”. En Sonia Muñóz y Jesús 
Martín-Barbero, Televisión y melodrama. Bogotá: Tercer mundo.

- y Sonia Muñóz (1992) Televisión y melodrama. Bogotá: Tercer mundo.

MARTÍN ETCHAREN, Laura (2005) "¿Amor en custodia o apocalypse now?" en El Ojo Digital, Buenos Aires. Consulta en línea: (www. elojodigital.com/espectaculos/2005/12/29/929.htm).

MATO, Daniel (1999) “Telenovelas: transnacionalización de la industria y transformaciones del género". En Néstor García Canclini y Carlos Juan Moneta (coords.) Industrias culturales e integración Latinoamericana. Buenos Aires: EUDEBA.

MAZZIOTTI, Nora (2005) "Modelos y tendencias hegemónicas en las telenovelas latinoamericanas: un recorrido por las principales estéticas". La revista del guión. Master de Escritura para Cine y TV. Universidad Autónoma de Barcelona. (En línea).

- (2003) La fuerza de la emoción. La telenovela: negocio, audiencias, historias. Ponencia en el seminario internacional "La internacionalización de la telenovela", organizado por la Escuela de Comunicaciones y Artes de la Universidad de São Paulo, octubre, 2003.

- (1996) La industria de la telenovela. México: Paidós.

MonsivÁIS, Carlos (2000) Aires de familia. México: Anagrama.

MORALES BURGOS, Olga y Kesmira Zarur Latorre (2006) "Ya está el clon gringo de Betty. La 'Fea' se vendió en setenta países y ahora se negocia su franquicia" en El Tiempo, 3 de marzo, Bogotá.

OROZCO, Guillermo (2002a) "La televisión en México". En Guillermo Orozco (coord.) Historias de la televisión en América Latina. Barcelona: Gedisa.

- (2002b) (coord.) Historias de la televisión en América Latina. Barcelona: Gedisa.

- (2004) "La televisión en México: indicios para reconstruir su itinerario no visible". En Oficios Terrestres, núm. 15 / 16, año X. La Plata.

PADILLA, Rebeca (2004) Relatos de telenovelas. Aguascalientes: Universidad Autónoma de Aguascalientes.

TELEVISIÓN AZTECA, S.A. DE C.V. Y SUBSIDIARIAS, Estado consolidado de resultados al 31 de diciembre de 2004. Consulta en línea: (www.irtvazteca.com/spanish/financiero/resultados.shtml). 
TORRES AgUILERA, Francisco Javier (1991) Análisis histórico de la exposición a las telenovelas en México (estudio descriptivo), tesis de maestría. México: Universidad Iberoamericana.

VASALLO DE LÓPEZ, María-Immacolata (2004) "Narrativas televisivas y comunidades nacionales: el caso de la telenovela brasileña". En Comunicación y Sociedad, núm. 2, nueva época, julio-diciembre.

- et al. (2002) Vivendo com a telenovela. São Paulo: Summus.

VERON, Eliseo y Lucrecia Escudero (comps.) (2004) Telenovela. Ficción popular y mutaciones culturales. Barcelona: Gedisa. 